\title{
Elections and Democracy: A Mirage for the Nation of Pakistan
}

\author{
Sheikh Nadeem Ahmed ${ }^{1}$
}

\begin{abstract}
Pakistan developed its political structures wherein power was vested in the inherited colonial institutions, the army, the bureaucracy and political elites comprising of feudal lords. In the post-independent scenario these structures continued to dominate the political landscape of Pakistan. Landed gentry also strengthened power while getting hold of major industries besides military also emerged as one the strongest economic entrepreneur in the post-independent scenario. The people of Pakistan have been striving to come out of their perpetual influence but it seems a far cry for them. On the other hand elections have been used as a tool by these structures to consolidate power and stamp dominance over people. This paper is an endeavor to investigate how elections have shaped the behavioral pattern of these dominant structures in the polity of Pakistan.
\end{abstract}

With the fall of Aurangzeb, the dazzling Mughal Empire crumbled sharply. The British, who had come to India for the purpose of trade, immediately noticed the rotten structure of Mughal Empire and planned to exploit golden sparrow for their politico-economic objectives. Later the War of Independence (1857) proved to be a swan song for the Mughal Empire. The British emerged as victorious. They successfully altered the political order of the India. The idiom of democracy was rephrased and representative institutions were introduced to serve political ambitions of British Raj in India. Ayesha Jalal rightly pointed out that political institutions introduced by the British were not meant to deliver democracy rather to ensure the uninterrupted dominance of the colonial rule. ${ }^{2}$. Despite expansion of enfranchisement and enlargement of the representative institutions towards the end of the colonial period, no real shift in power imbalance resulted and power remained in the hands of military, bureaucracy and feudal gentry. The institution of bureaucracy was designed with objectives of running administrative affairs as well as drafting democracy in line with the whims and caprices of British Raj. It was also responsible for holding elections. It had to design electoral laws, prepare the list of the voters and the candidates, election symbols, laying out election procedures, schedules and announcing the results. Thus it established preponderance of bureaucracy in political process.

In the post-Independent scenario, the early demise of the founder, the assassination of Prime Minister Liaqat Ali Khan and the inability of the politicians to cope with growing political and economic crisis paved a ground for military- bureaucratic elements to ascertain dominance. Malik Ghulam Muhammad, Skindar Mirza became Governor Generals and used power arbitrarily for self motivated objectives. With the imposition of Martial Law in 1958 bureaucracy adopted a new role, yet remained subservient to the interests of military ruler. Firstly it helped in establishing some semblance of democracy at grass root level in 1959. Secondly it facilitated Ayub Khan in the process of acquiring legitimacy through manipulated Presidential referendum in 1960. Mohammad Waseem observed that military altered the entire political order in collaboration with bureaucracy. The new system was designed to ensure controlled democracy. ${ }^{3}$ Ayub Khan also brought political fractionalization. In this regard Muslim League was split by military dictator. The military ruler smartly carved Conventional League out of Muslim League. However the dissenters of Conventional League formed Council League to challenge the autocracy of a military ruler.

Sadly speaking the people of Pakistan remained without real democracy for more than two decades. Fist general elections on the basis one man one vote took place in 1970. Finally public opinion was translated into voting behavior. Zulfiqar Ali Bhutto representing Pakistan People's Party won the sympathies of general public in West Pakistan and Majeeb-ur-Rehman, the leader of Awami League earned popularity in the Eastern part of Pakistan. Many factors were responsible behind the success of Pakistan People's Party in West Punjab. Firstly the Slogan of 'roti', 'kapra', 'makan' greatly attracted the people of Punjab and Sindh. Secondly the process of urbanization, modernization and economic development achieved during the period of Ayub Khan led to the rise of new political awakening. The urban and rural people were captivated by the charisma of

\footnotetext{
${ }^{1}$ Sheikh Nadeem Ahmed is serving as Lecturer in the Department of Political Science at Minhaj University Lahore, Pakistan

2 Ayesha Jalal, Democracy and Authoritarianism in South Asia: A Comparative and Historical Perspective, (England: Cambridge University Press, 1995), pp.29-65

${ }^{3}$ Mohammad Waseem, Democratization in Pakistan: A Study of the 2002 Election(New York: Oxford University Press,2006), p. 4
} 
Zulifiqar Ali Butto and supported him during general elections. Burki and Baxter found the relatively fast developing 'urban' and rural 'tehsils' of Punjab and Sindh overwhelmingly voted for PPP. ${ }^{4}$

The aftermath of general elections proved to be highly detrimental for the national integration. The rise of political ruffles between Majeeb-ur-Rehman and Zulfiqar Ali Bhutto over the issue of constituting new political government resulted in the breakup of Pakistan. One can argue that military- bureaucratic involvement remained unbridled during this crisis. One of the factors which anchored anti-state feelings among Bengalis was inveterate hostility of these institutions towards them.

The fact remains that despite of wining thumping majority in Punjab and Sindh, Pakistan People's Party failed to bridle the power brokers i-e army and bureaucracy and feudal elites. Bhutto tried to revamp the institution of bureaucracy by removing corrupt bureaucrats but he could not persist with this policy for long, eventually, he had to reinstate them. On the other hand the functional mechanism of Pakistan People's Party remained in the hands of big feudal lords who enjoyed powerful positions throughout his tenure. They dominated the rural constituencies and brought laurels for him in the election. Zulifiqar Ali Bhutto failed to break the monopoly of feudal lords. Having feudalistic background he was also unsuccessful in the execution of Land Reforms. Consequently his land reforms fell apart.

Zulfiqar Ali Bhutto completed his first democratically elected tenure with the help of fragile party cadres dominated by old feudal elites. He announced to hold second national elections before the expiry of his ongoing term. Lawrence Ziring opinionated that he wanted to get rid of obstructionist elements within his party. ${ }^{5}$ The result of general elections 1977 was a source of great rejoices for Zulifqar but not for PNA (Pakistan National Alliance) that left no time in putting accusing finger at massive rigging. Although Bhutto got 108 out of 116 NA seats from Punjab and earned $94.6 \%$ seats by wining only 61 percent of the vote ${ }^{6}$ but failed to capitalize on his victory. PNA alleged PPP for using state machinery in changing the results of the polls. The growing resentment among PNA over the results of the elections led to anti-Bhutto movement. It rang alarming bells in the hawks of Bhutto's party. Initially Bhutto was un-nerved but had to come to speaking terms with them. He attempted to resolve political crisis through political negotiations however it was too late to bell the cat. The incohesive ideological orientation, policy of nationalization, political issues bedeviled the entire governmental machinery. The political system was exposed to vulnerability and the sate of Pakistan saw another military coup in 1977 by Zia-ul-Haq. This came to be commonly known as 'Operation Fair Play'. Interestingly, Bhutto had appointed Zia ul Haq as chief of Army Staff. Due to his piety, patriotism and professionalism, he was convinced that Zia-ul-Haq would pay lip services to the political orders of the Prime Minister but Nizam-eMustafa agitation turned him from an apolitical soldier to a successful coup-maker. ${ }^{8}$ Zia-ul-Haq expressed unwillingness to stay in power for long and promised to hold election within 90 days ${ }^{9}$. However, instead of becoming a man of his words he embarked upon consolidating his power. He also felt imperative to use local self government system as a mean to achieve self motivated objectives. He made arrangements for holding local bodies elections in 1979 and then in 1983. Zia-ul Haq just like his predecessor used referendum as a tool for perpetuating his rule in 1984 .

Ian Talbot maintained that referendum was hastily arranged in December, 1984, designed to provide him with semblance of a popular mandate and legitimacy before elections. ${ }^{10}$ After holding referendum he became the president for next five years. Later he announced to hold elections for national and provincial assemblies which were supposed to be held on $25 \mathrm{Feb} 1985$ and $28 \mathrm{Feb} 1985^{11}$. His decision to hold non party based elections led Opposition parties to register protest against it. They out rightly rejected his plan and started a movement for the restoration of democracy MRD (Movement of Restoration for Democracy). They also termed these elections as 'deaf and dumb' because public meetings and processions were also proscribed. ${ }^{12}$ Hamid Khan categorically stated that political parties were deliberately relegated and opposition' leaders were detained unlawfully for the period of elections. ${ }^{13}$ Elections were held in a peacefully. The turn-out for national assembly was $53.69 \%$. At provincial level the turnout was $57.37 \%{ }^{14}$.

\footnotetext{
${ }^{4}$ S. J. Burki and C. Baxter, Socio-economic Indicators of the Peoples Party Vote in the Punjab: A study at the Tehsil Level, (Islamabad: Islamabad University Press, 1975), pp. 167-169

${ }^{5}$ Lawrence Ziring, Pakistan, The Campaign before the Storm, Asian Survey, July 1977, pp. 584-590

${ }^{6}$ For information See Chief Election Commission of Pakistan, General Elections in Pakistan 1977

${ }^{7}$ Hamid Khan, Political and Constitutional History of Pakistan, (New York: Oxford University Press, 2001), p.329

${ }^{8}$ Dr. Tahir Kamran, Democracy and Governance in Pakistan, (Lahore: South Asia Partnership,2008), p.103

${ }^{9}$ Hassan Askari Rizvi, The Military and Politics in Pakistan, (Lahore: Progressive Publishers, 1974), p.240

${ }^{10}$ Ian Talbot, Pakistan A Modern History,(New York :St. Martin's Press, 1998PP.260-261

${ }^{11}$ Hamid Khan, op.cit, p.350

${ }^{12}$ Hassan Askari Rizvi, The Civilization of Military Rule in Pakistan, Asian Survey 26,no.10 (October 1986), p.1069

${ }^{13}$ Hamid Khan, op.cit, p.373

${ }^{14}$ Report on the General Election 1985, Volume II, Election Commission of Pakistan, Islamabad, pp.73,205
} 


Distribution of Seats in the National Assembly
\begin{tabular}{|l|l|l|l|l|l|}
\hline Province/ Area & Muslim & Women & Christian & Hindu & Buddhist \\
\hline Islamabad & 1 & - & - & - & - \\
\hline F.A.T.A & 8 & - & 4 & - & - \\
\hline Punjab & 115 & 12 & - & 4 & - \\
\hline Sindh & 46 & 4 & - & - & - \\
\hline NWFP & 26 & 2 & - & - & - \\
\hline Balochistan & 11 & 2 & - & - & - \\
\hline Total & 207 & 20 & 4 & 4 & - \\
\hline
\end{tabular}

\section{Provincial Assemblies ${ }^{16}$}

\begin{tabular}{|l|l|l|l|l|}
\hline Province & Muslim & Women & Minorities & Total \\
\hline Balochistan & 40 & 2 & 3 & 45 \\
\hline N.W.F.P & 80 & 4 & 3 & 87 \\
\hline Punjab & 240 & 12 & 8 & 260 \\
\hline Sindh & 100 & 5 & 9 & 114 \\
\hline Total & 460 & 23 & 23 & 506 \\
\hline
\end{tabular}

\section{Members of Various Political Parties Taking Part in 1985 Elections $^{17}$}

\begin{tabular}{|c|c|c|c|c|c|}
\hline Parties & Punjab & Sindh & N.W.F.P & Balochistan & Total \\
\hline Pakistan People's Party & 31 & 32 & 10 & 6 & 79 \\
\hline Pakistan Muslim League & 55 & 22 & 13 & 66 & 96 \\
\hline Jamaaat-e-Islami & 34 & 18 & 7 & 2 & 61 \\
\hline Jamait Ulma-e-Pakistan & 8 & 4 & 1 & 0 & 13 \\
\hline Jamait-Ulma-e-Islam & 2 & 2 & 4 & 0 & 8 \\
\hline National Awami Party & 2 & 0 & 0 & 0 & 2 \\
\hline Pakistan Democratic Party & 1 & 0 & 0 & 0 & 1 \\
\hline National Democratic Party & 0 & 0 & 1 & 1 & 2 \\
\hline Inqalab Mahaz & 1 & 0 & 0 & 0 & 1 \\
\hline PML (ZS) & 1 & 2 & 0 & 0 & 3 \\
\hline Himaya-t-Zai & 2 & 0 & 0 & 0 & 2 \\
\hline Sawad-e-Azam & 0 & 3 & 0 & 0 & 3 \\
\hline NAP (PK) & 0 & 0 & 0 & 1 & 1 \\
\hline ICP & 0 & 3 & 0 & 0 & 3 \\
\hline
\end{tabular}

The formation of the government under Mohammad Khan Junejo was greatly hauled. Zia was more ambitious to have a Prime Minister who should not pose any kind of challenge to his political ambitions. The critics of Zia-ul-Haq were of the opinion that $8^{\text {th }}$ Amendment as well as holding non party elections were meant to push Pakistan People's Party politically back to the wall.

The tragic demise of Zia in 1988 forced the apex Court of Pakistan to hold next general elections on party basis. ${ }^{18}$ The anti-Bhutto elements in cooperation with the military - bureaucratic establishment formed IJI (Islmi Jahmoori Ittehad) to oppose PPP in coming elections. Muhammad Waseem pointed out military and bureaucracy supported the Muslim League. ${ }^{19}$ Benazir Bhutto emerged as a shining moon among stars. Her personality was of no match with the leaders of IJI. Despite being supported by traditionalist anti-PPP forces IJI had to cut a sorry figure in 1988 elections. The sympathy vote of Zulfiqar Ali Bhutto also helped Benazir Bhutto in stamping dominance over political rivals. Pakistan People's Party won 93 seats out of 205 seats and IJI won 53 seats. At National Level Pakistan People's Party had 38\% votes. On the other hand IJI got $30.2 \%$. In provincial elections of Punjab, IJI was victorious and formed government in Punjab ${ }^{20}$. Benazir Bhutto assumed power with full zeal but failed to capitalize on it. She was embroiled into political conflict with the President. Her government was dissolved in 1990. Ghulam Ishaq being the protégé of Zia accused her of massive corruption, political dysfunctionalism, and poor governance. The 1990s national elections symbolically aimed at

\footnotetext{
${ }^{15}$ Politics without Parties, A Report on the 1985 Party less Election in Pakistan, (Society for the Advancement of Education SAHE), Lahore 1988, PP.11-12-13

16 ibid

17 ibid

${ }^{18}$ Hamid Khan, op.cit, p.390

${ }^{19}$ Mohammad Waseem, op.cit, 16

${ }^{20}$ Andrew R. Wilder, The Pakistani Voter: Electoral Politics and Voting Behavior in Punjab, (Karachi; Oxford University press, 1999 ) p.31
} 
giving legal cover to the actions of Ghulam Ishaq. Anwar.H Syed opinionated the 1990 election was a referendum on the legitimacy of the president action of removing Benazir Bhutto from office. ${ }^{21}$ Nawaz Sharif who was out and out an industrialist reflected a new trend in the electoral politics as political elites emerging from industrial background but fact remained the same that most of the politicians were either nurtured by military-bureaucratic establishment or came from feudal linkages. The newly elected Prime Minister Mian Nawaz Sharif was aspiring for striking balance between the power syndromes of two top executives namely prime minister and the president. Thus resulted into political crisis, the political turmoil was brought to an end when Prime Minister and the President both had to resign from political offices. The people of Pakistan had to go for a new round of election. The general elections of 1993 were regarded as free and fair. The caretaker government remained impartial in holding elections. The coalition of Pakistan People's Party and Pakistan Muslim Junejo contested elections against PML (N). PPP and its Coalition partner were able to defeat PML (N). Once again Benazir Bhutto emerged victorious and became Prime minister.

The government of PPP enjoyed power for couple of years. President Farooq Ahmed Khan Leghari used article 58 (2) (B) of the Constitution and dissolved the national assembly on grounds bad governance. In 1997 elections about twenty million votes were cast. PML (N) won a landslide victory and secured 134 seats out of 204 seats. It obtained 45.9 percent of the total vote's caste. PPP won only 18 seats and $21.8 \%$ of the total vote's caste ${ }^{22}$. Mian Nawaz Sharif saddled into power having 2/3 majority at his back.

One of the very first bold steps he took was to do away with the discretionary powers of the President. He introduced $13^{\text {th }}$ Amendment in the Constitution and got rid of article 58 (2) (B) which had been a source of removing political governments. The power of the President to appoint governors was also watered down. Now, the President was bound to follow advice of the Prime minister. The president was reduced to ceremonial position. Realizing his insignificance in state matters, President Farooq Ahmed Khan Leghari resigned in disgrace. The Senate Chairman Mr. Waseem Sajjad remained acting President until Justice (Retired) Rafiq Tarar was elected as President on $31^{\text {st }}$ December 1997.

In the decade of democratization political manipulations and horse trading, defections had frequently taken place. The members of the Parliament elected on the ticket or support of one political party would defect their benefactor and used to switch loyalty for want of prestigious position or financial gains. Therefore, Nawaz Sharif used his 2/3 majority and incorporated $14^{\text {th }}$ Amendment. According, a member of the Parliament elected on party ticket was not allowed to switch over to another party. While doing so, he would relinquish his political office. This Amendment made head of political party a powerful leader on whose recommendation a member will be de-notified by the Election Commission. The defection clause of the Constitution silenced the dissenters within a party. Even abstention, which has never been equated with defection in established democracies, was prohibited.

A selective weapon to victimize opposition was also introduced. An Ehtisab Act 1997 was enacted and Ehtisab Cell was set up under Senator Saif-ur-Rehman, (a close confidant of Mian Nawaz). The accountability drive was confined to opponents only. Mian Nawaz and his cronies were exempted from such proceedings. Nawaz Sharif had come into power partly because of the Chief Justice Sajjad Ali Shah who upheld President Leghari's decision but soon differences between the Prime Minister and Chief Justice of Pakistan got surfaced. The sources of friction and antagonism were as follows:

- Justice Sajjad took suo moto action of the handcuffing of certain officers of WASA (Water and Power Development Authority) Faisalabad on the verbal order of the Prime Minister and had set them free. Nawaz Sharif felt demeaned.

- Justice Sajjad opposed the creation of parallel court structure of anti-terrorist courts established by Nawaz Sharif government for speedy trials. Appeals against the decision of anti-terrorist courts were not falling in the jurisdiction of either High Court or Supreme Court.

- Chief Justice recommended elevation of five High Court Judges to Supreme Court. Prime Minister Mian Nawaz Sharif was reluctant to notify. The confrontation between Chief Justice and Prime Minister was escalating day by day. It reached to its climax when the Chief Justice suspended the $14^{\text {th }}$ Amendment in the Constitution, which prohibited the defection of members of assemblies. There ensued a constitutional war of attrition. There was a strong reaction with words of criticism against Justice Sajjad in the Parliament, the Prime Minister calling the suspension of orders as 'illegal and unconstitutional' and against the supremacy of the Parliament. These speeches led to contempt of Court proceedings against the Prime Minister and party members in the Supreme Court. In order to protect Prime Minister from contempt proceedings, Parliament hurriedly passed Contempt of Court (Amendment) Bill. The Chief Justice issued as interim order restraining the President from signing the Bill. On $28^{\text {th }}$ November 1997, as the Supreme Court took up the Contempt case but Muslim League (N) workers assaulted the Supreme Court building. It was indeed

\footnotetext{
${ }^{21}$ Anwar.H Syed, The Pakistan People's Party and the Punjab: National Assembly Elections, 1988 and 1990, Asian Survey, July 1991, p. 584

${ }^{22}$ Andrew R. wilder, op.cit, p. 222
} 
one of the most shameful assaults on the courts in the judicial history. The Chief Justice requested for Army help but it was not given. The controversy came to an end on $23^{\text {rd }}$ December 1997 when Federal Government de-notified Justice Sajjad and notified Justice Ajmal Mian as the Chief Justice of Pakistan.

Nawaz Sharif was keen to accumulate more powers while doing so he also ran into trouble with the Army. The Army Chief Jehangir Kramat while addressing to the Naval War Academy on $5^{\text {th }}$ October 1998 proposed the establishment of National Security Council for addressing important national issues. Two days later, Karamat was sacked by Nawaz. He was replaced by General Pervaiz Musharaf. The sudden removal of an Army Chief caused resentment and a sense of humiliation in the rank out file of the Army. Later on, Kargil Crisis (1999) further widened gulf between Army and Nawaz Sharif. The prime minister was preparing to sack General Perviaz Musharaf and appoint Lt. General Zia-ud-din who was very junior to many other Lt. Generals. Meanwhile, General Musharaf who was returning from an official visit to Sri Lanka was denied landing in Pakistan. As a result Army intervened and the government of Nawaz Sharif was toppled down. The military coup was bloodless and no prominent reaction was demonstrated by the political parties, media and civil society. The heavy mandate claimed by the Prime minister was moonshine. The masses were indifferent from the ongoing political upheaval.

With the removal of Nawaz Sharif and Army taking over control of the country's affairs, a new phase in the political and constitutional evolution started off. The Chief of Army staff neither imposed Martial Law nor did assume the office of the President. He rather proclaimed the state of emergency and suspended the assemblies and coined a new term, 'Chief Executive' to exalt himself as the real sovereign of Pakistan. The military ruler successfully sought the help of Supreme Court for gaining dejure position. The apex Court used old idiom 'the law of necessity' to justify military take over. Once the Supreme Court had given legal cover to military regime by delegation authority even to amend the constitution, the Chief Executive went step further and promulgated President's Succession Order 2001. The order empowered the Chief Executive to become President of Pakistan. He removed then President Rafique Tarar unceremoniously and stepped into the shoes of President. Like previous military rulers, Musharraf also decided to hold referendum, it was held on $30^{\text {th }}$ April 2002. Many local and international observers lack luster turnout in the referendum. According to the official figures released by the Election Commission of Pakistan 97.5 percent of people voted for General Pervaiz Musharraf; while 2.5 percent rejected his candidature ${ }^{23}$.

After saddling into political office as a head of the state he used elections to establish his hegemony over democratic institutions. For putting his political imagination into a reality he laid the foundation of PML-Q (Pakistan Muslim League Quaid-e-Azam). The dissenters of PML-N and PPP joined this party. Hence the traditionally strong links of the PML to the civil and military establishments along with the reputation of many leaguers as 'men of easy political virtue "easily enticed to switch their allegiances ${ }^{24}$. In order to debar the leaders of two major political parties Musharraf issued Executive Order on July6, 2002, No19, stipulating that no political candidate could hold the position of Prime minister for more than two terms.

\section{Distribution of Seats in the National Assembly ${ }^{25}$}

\begin{tabular}{|l|l|l|l|}
\hline Province/ Area & General Seats & Women & Total \\
\hline Islamabad & 2 & - & 2 \\
\hline F.A.T.A & 12 & - & 12 \\
\hline Punjab & 148 & 35 & 183 \\
\hline Sindh & 61 & 14 & 75 \\
\hline NWFP & 35 & 8 & 43 \\
\hline Balochistan & 14 & 3 & 17 \\
\hline Minorities & 0 & 0 & 10 \\
\hline Total & 272 & 60 & 342 \\
\hline
\end{tabular}

More than 100 political parties got registered to take part in these elections but only sixteen ended up wining one or more than one seats in the National Assembly. The following table gives an overview of the major parties that swept polls in 2002 elections

Pakistan National Assembly Results 2002

\begin{tabular}{|l|l|l|l|l|l|l|l|l|l|l|l|}
\hline & PPP & PML Q & PML N & MMA & NA & MQM & ANP & INDP & OTHER & TOTAL & $\begin{array}{l}\text { OUT } \\
\text { OF }\end{array}$ \\
\hline Punjab & 34 & 66 & 15 & 3 & 7 & & & 15 & 6 & 146 & 148 \\
\hline Sindh & 27 & 4 & & 7 & 5 & 13 & & 1 & 4 & 61 & 61 \\
\hline NWFP & & 4 & & 29 & & & & & 2 & 35 & 35 \\
\hline Balochistan & & 2 & 1 & 6 & 1 & & & 1 & & 12 & 14 \\
\hline
\end{tabular}

\footnotetext{
${ }^{23}$ Tahir Kamran, Democracy and Governance in Pakistan, (Lahore: Sheikh Ghulam Ali and Sons), p. 185

${ }^{24}$ Aziz Siddqui, Whose League Is It Any way?, News line , September, 1993, p.49

${ }^{25}$ Data has been compiled from Election Commission of Pakistan
} 


\begin{tabular}{|l|l|l|l|l|l|l|l|l|l|l|l|}
\hline FATA & & & & 7 & & & & 5 & 1 & 12 & 12 \\
\hline Islamabad & 1 & & & 1 & & & & & & 02 & 02 \\
\hline Total & 62 & 76 & 16 & 53 & 13 & 13 & & 22 & 13 & 268 & 272 \\
\hline
\end{tabular}

These elections marked the formal restoration of democracy in Pakistan following three years of military rule by General Pervaiz Musharraf ${ }^{26}$. He employed different strategies to undermine the functional dynamics of other institutions and altered the power imbalance in Pakistan with an objective to bear out the corelation of military and bureaucracy, the two dominant power houses in the political system of Pakistan. The results of the elections gave immense pleasure to military personnel who engineered elections to develop PliantParliament in Pakistan. The system of democracy was to be manifested according to the whims of the military ruler.

He was not the first one, who used such mechanism to prolong his rule rather his predecessors did the same to shape political system by introducing many devices. While looking at the political system of Pakistan, the following table demonstrates the picture of political system and various strategies adopted by military ruler. $^{27}$

\begin{tabular}{|c|c|}
\hline Strategy & Examples \\
\hline Rigging elections & $\begin{array}{ll}- & 1951 \text { Punjab Assembly Elections } \\
- & 1977 \text { National and Provincial Assembly } \\
\text { Elections } & \\
- & 1984 \text { and } 2002 \text { Presidential Referendums }\end{array}$ \\
\hline Pre- poll and post poll manipulation to achieve desired objectives & $\begin{array}{l}\text { - All elections, but particularly the } 1990 \\
\text { and } 2002 \text { elections }\end{array}$ \\
\hline Holding presidential referendums to bypass Constitution and Parliament & $\begin{array}{ll} & \text { General Ayub Khan. } 1960 \\
- & \text { General Zia ul Haq } \\
\text { - } & \text { General Pervaiz Musharraf }\end{array}$ \\
\hline $\begin{array}{l}\text { Holding local rather than provincial and National elections to gain the legitimizing } \\
\text { effect of elections, deflect attention from national politics, and create local } \\
\text { constituencies dependent on military for survival }\end{array}$ & $\begin{array}{ll}- & \text { Basic Democracies, } 1959,1960 \text { and } 1964 \\
- & \text { Local Bodies, } 1979,1983,1987,1991 \\
- & \text { Local Government, 2001 }\end{array}$ \\
\hline $\begin{array}{l}\text { Using Pakistan's geographical importance to get Western powers to turn a blind eye } \\
\text { to the abuse of democratic norms }\end{array}$ & $\begin{array}{l}\text { - Ayub pro- U.S. stance in the Cold War } \\
\text { politics of 1960s } \\
\text { Z Zia's 'front line' against the Soviet } \\
\text { Union in Afghanistan during the } 1980 \text { s } \\
\text { ' Musharraf's support for the U.S. backed } \\
\text { 'war against terror' in 2001 }\end{array}$ \\
\hline $\begin{array}{l}\text { Creating a malleable judiciary that will sanction unconstitutional military actions, as } \\
\text { well as the writing and amending of constitutions in order to strengthen presidential } \\
\text { powers at the expense of those elected }\end{array}$ & $\begin{array}{l}\text { - Ayub's coup and } 1962 \text { constitution } \\
\text { - Zia's coup and Eight Amendment to the } \\
1973 \text { constitution } \\
\text { Order of } 2002\end{array}$ \\
\hline Weakening political parties by holding non-party rather than party -based elections & 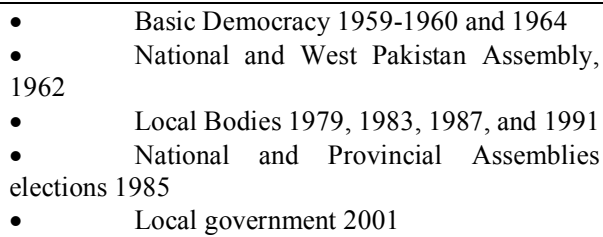 \\
\hline $\begin{array}{l}\text { Weakening political parties and facilitating the manipulation of results by holding } \\
\text { indirect rather than direct elections }\end{array}$ & $\begin{array}{l}\text { - Using 'Basic Democrats' as an Electoral } \\
\text { College in the Presidential referendum } 1960 \text { and } \\
1965 \\
\text { Elections in } 1962 \text { and } 1965\end{array}$ \\
\hline Promising but postponing elections and conceal elections & $\begin{array}{ll}- & 1947-1958 \\
- & 1977-1979\end{array}$ \\
\hline
\end{tabular}

His ambition to stay in power made him the most supercilious military leader of Pakistan. Internally he followed the policy of political fragmentation and externally earned the support of the hegemon of the world on 'war on terror'. He was having the smooth sailing without any hitch but power corrupts and absolute power corrupts absolutely. By the virtue of constitutional engineering he had got upper hand over every institution. Under his auspices his party completed first democratically tenure successfully. Later conflict with judiciary, Lal Masjid adventure brought his popularity down. Another event that added fuel to fire was the assassination of Benazir Bhutto which ignited anti-government feelings that set the stage for the next elections.

\footnotetext{
${ }^{26}$ Andrew Wilder in, Pakistan on the Brink Politics, Economics and Society, ( Karachi: Oxford University Press), p.10

${ }^{27}$ Source: Andrew Wilder, op.cit. p.17
} 
The sympathy vote of Benazir's death was a decisive factor that brought PPP in power again. The PML (N) and its leader due to the policy of political reconciliation had come back and they too took part in these elections. This time his sponsored party could not bring laurels for him. He was shocked to see the post elections scenario. His two rival factions collaborated to form government. The results of the elections were as follows.

\section{Results of General Elections $2008^{28}$}

\begin{tabular}{|l|l|l|l|l|l|}
\hline Party & $\begin{array}{l}\text { National } \\
\text { Assembly }\end{array}$ & $\begin{array}{l}\text { Punjab } \\
\text { Assembly }\end{array}$ & $\begin{array}{l}\text { Sindh } \\
\text { Assembly }\end{array}$ & $\begin{array}{l}\text { Balochistan } \\
\text { Assembly }\end{array}$ & $\begin{array}{l}\text { NWFP } \\
\text { Assembly }\end{array}$ \\
\hline Pakistan People's Party & 87 & 80 & 69 & 7 & 17 \\
\hline $\begin{array}{l}\text { Pakistan Muslim League } \\
\text { Nawaz }\end{array}$ & 67 & 104 & 0 & 0 & 5 \\
\hline $\begin{array}{l}\text { Pakistan Muslim League } \\
\text { Quaid }\end{array}$ & 41 & 68 & 10 & 18 & 5 \\
\hline Muttahida Qumi Movement & 19 & 0 & 39 & 0 & 0 \\
\hline Awami National Party & 10 & 0 & 2 & 2 & 31 \\
\hline Muttahida Majils-e-Amal & 6 & 2 & 0 & 7 & 10 \\
\hline $\begin{array}{l}\text { Pakistan Muslim League } \\
\text { Functional }\end{array}$ & 4 & 3 & 7 & 0 & 0 \\
\hline National People's Party & 2 & 0 & 3 & 0 & 0 \\
\hline $\begin{array}{l}\text { Pakistan People's Party } \\
\text { Sherpao }\end{array}$ & 1 & 0 & 0 & 0 & 6 \\
\hline $\begin{array}{l}\text { Balochistan National Party } \\
\text { Awami }\end{array}$ & 1 & 0 & 0 & 5 & 0 \\
\hline Independents & 28 & 35 & 0 & 12 & 20 \\
\hline Total Results & 266 & 292 & 130 & 51 & 94 \\
\hline Total Seats Contested & 268 & 293 & 13 & 51 & 96 \\
\hline
\end{tabular}

The results of the elections signaled the disappearance of military ruler who wielded to power forcibly and moved from defecto sovereign to dejure sovereign. It also exposed the hollowness of PML (Q) that was defeated pathetically in these elections. The old rivals of military rule PPP and PML (N) swept polls and out numbered their political opponents. Both parties vowed vehemently to restore the 1973 constitution and pledged to work together for flourishing democracy. In reality the honey moon period between two parties did not last long. The demand of PML (N) to make president accountable before the courts could not be addressed and PPP government provided safe exit to General Pervaiz Musharraf. Another source of confrontation was the issue of reinstating Chief Justice Iftikhar Choudhry who had been deprived of his job by the President unlawfully

The political crisis continued to widen but due to back stairs influence of army, this crisis was averted. Later on, the Co-Chairman of Pakistan People's Party Asif Ali Zardari became the head of state. His policy of political reconciliation worked extremely well for him. He was able to complete his democratically elected tenure of five years. The smooth transition of power in 2013 general elections has been one of the positive features of Pakistan People's Party. However, this democratic order is still manipulated by feudal lords, business elites and military- bureaucratic establishment.

\section{Conclusion}

Elections complement democracy but in Pakistan elections have been a source of dominance for power structured institutions. The legacy of British rule is still continuing one way or another. Civilian leadership looks incapacitated to capitalize upon democratic idiom rather they have been at logger heads over self designed objectives. Their perpetual political differences has greatly weakened democratic edifice. To cap it all one can say that we have a closed political system in which the civil and military bureaucracy sometimes operate covertly and in the presence of political and economic crisis they function overtly thus become the key players of governance. When military takes over, feudal gentry with no hyperbolism play a policy of second fiddle. Thus the power of the state remains in the hands of military and bureaucratic and landed magnates who in reality are the product of British legacy.

\footnotetext{
${ }^{28}$ Data has been compiled from the official web site of Election Commission of Pakistan
} 